DALAT UNIVERSITY JOURNAL OF SCIENCE Volume 9, Issue 2, 2019 81-93

\title{
A REVIEW ON STERCULIA FOETIDA L. AND IT'S POTENTIAL FOR DEVELOPMENT IN THE DRY AREAS OF VIETNAM
}

\author{
Pham Trong Nhan ${ }^{a^{*}}$, Le Hong Ena, Huynh Thi Kieu Trinh ${ }^{\mathrm{a}}$ \\ ${ }^{a}$ The Forest Science Institute of Central Highlands and South of Central Vietnam, Lamdong, Vietnam \\ ${ }^{*}$ Corresponding author: Email: ptnhan@vafs.gov.vn \\ Article history \\ Received: September $6^{\text {th }}, 2018$ \\ Received in revised from: October $10^{\text {th }}, 2018 \mid$ Accepted: October $11^{\text {th }}, 2018$
}

\begin{abstract}

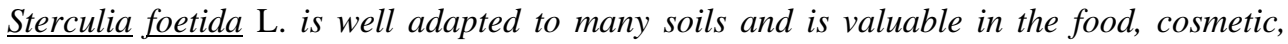
medicine, pesticides, bio-oil, beverage, and furniture industries. More knowledge is needed about its value and uses, including resin tapping and storage, propagative methods and cultural uses. The literature on Sterculia foetida L. was summarized to provide guidance and to bring together key recommendations needed to successfully rehabilitate degraded lands and forests. Based on this review, we build on recent work to provide critical advice and state explicit objectives related to planting and developing of this species in Vietnam.
\end{abstract}

Keywords: Oil; Propagation; Resin; Seed; Sterculia foetida L.

DOI: http://dx.doi.org/10.37569/DalatUniversity.9.2.504(2019)

Article type: (peer-reviewed) Full-length review article

Copyright $(92019$ The author(s).

Licensing: This article is licensed under a CC BY-NC-ND 4.0 


\title{
TỔNG QUAN VỀ CÂY TRÔM VÀ TIỀM NĂNG PHÁT TRIỂN LOÀI NÀY Ở MỘT SỐ VÙNG KHÔ HẠN TẠI VIỆT NAM
}

\author{
Phạm Trọng Nhân ${ }^{a^{*}}$, Lê Hồng Én ${ }^{\mathrm{a}}$, Huỳnh Thị Kiều Trinh"a
}

${ }^{a}$ Viện Khoa học Lâm nghiệp Nam Trung Bộ và Tây Nguyên, Lâm Đồng, Việt Nam

"Tác giả liên hệ: Email: ptnhan@vafs.gov.vn

Lịch sử bài báo

Nhận ngày 06 tháng 09 năm 2018

Chỉnh sửa ngày 10 tháng 10 năm 2018 | Chấp nhận đăng ngày 11 tháng 10 năm 2018

\section{Tóm tắt}

Cây Trôm cho thấy khả năng thích ưng tốt với nhiều loại đất đai và mang lại nhiều giá trị khác nhau nhu thưc phẩm, mỹ phẩm, y học, thuốc bảo vệ thực vật, dầu sinh học, nuớc giải khát, và đồ nội thất cho cuộc sống con người. Vì vậy, để đánh giá toàn diện cần có nhiều thông tin về giá trị và cách sủ dụng, phương pháp khai thác và bảo quản nhựa, nhân giống và gây trồng. Các đánh giá được báo cáo tóm tắt trong nghiên cứu này và đưa ra nhũng khuyến cáo cần thiết để phục hồi thành công đất đai và rùng bị suy thoái. Trên co sở đó, chúng tôi tổng hợp thông tin tù nhũng nghiên cứu gần đây để cung cấp nhũng chỉ dẫn hưu ích nhằm xác định vùng trồng thích nghi và phát triển loài cây này tại Việt Nam.

Từ khóa: Cây Trôm; Dầu; Hạt giống; Nhân giống; Nhựa.

DOI: http://dx.doi.org/10.37569/DalatUniversity.9.2.504(2019)

Loại bài báo: Bài báo tổng quan có bình duyệt

Bản quyền @ 2019 (Các) Tác giả.

Cấp phép: Bài báo này được cấp phép theo CC BY-NC-ND 4.0 


\section{INTRODUCTION}

Sterculia foetida L. (Sterculiaceae) has been an important source of natural timber and non-timber resources for a long period of human history. Its leaves and bark are traditionally used as an aperient, a diaphoretic, a diuretic, etc. It is grown during dry seasons and is currently found in the tropical zones of Australia, Africa, and Asia. It is a native plant in Australia, Bangladesh, Djibouti, Eritrea, Ethiopia, India, Indonesia, Kenya, Malaysia, Myanmar, Oman, Pakistan, Philippines, Somalia, Sri Lanka, Tanzania, Thailand, Uganda, Yemen, Republic of Zanzibar, Vietnam, Laos, and Cambodia (Hocking, 1997; Lim, 2011; Orwa, Mutua, Kindt, Jamnadass, \& Anthony, 2009; \& Pham, 2000) (Figure 1). In Vietnam, it can be found in deciduous forests in southern provinces and is currently planted in many parts of Vietnam, such as: Daklak, Binhthuan, Ninhthuan, and Vinhlong provinces. The investigational history of this species, concerning the progress that has been made in research on phytochemical and pharmacological activities, is available (Kavitha, Vadivu, \& Radha, 2015). However, a systematic review that summarizes all its values and uses, resin tapping and storage, propagative methods and cultural uses has never been reported. Herein, a comprehensive review of the literature is made, reporting the distribution, propagation and planting of the species in different dry areas of Vietnam, with the aim of providing more direction for planting this valuable species.

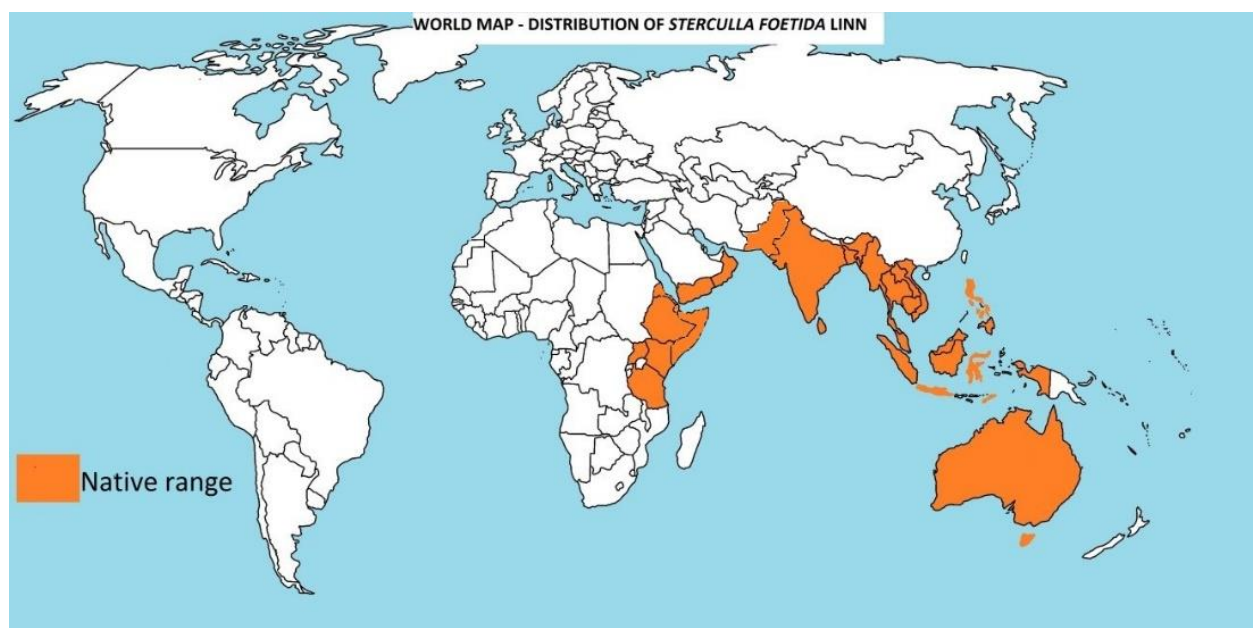

Figure 1. Map showing the global distribution of native areas of Sterculia foetida $\mathbf{L}$.

Source: Hocking (1997); Lim (2011); Orwa et al. (2009); and Pham (2000) (edited by the authors).

\section{METHODS}

This review examines biological characteristics, ecological requirements, spatial distribution, geographical diversity, propagation and planting, resin tapping and storage of Sterculia foetida's products as found in books and other publications, both worldwide and in Vietnam.

The research also surveyed fieldwork in Daklak and Ninhthuan provinces. At least two sites were identified where Sterculia foetida L. was planted in drylands with 
the same environmental conditions of soil, weather, and other factors. Some information was collected to provide a foundation for assessing the potential of developing this species in many dry regions of Vietnam.

\section{RESULTS}

\subsection{Values and uses}

Sterculia foetida L. resin plays significant roles in medicine. It helps prevent swelling, irritation to intestines and facilitates bowel movement. In oriental medicine, the resin is known to be an herbal that is high in minerals and trace elements, tastes sweet and cool, is especially good for digestion, and treats diseases such as pimples, dysentery, and cirrhosis due to ingredients containing D-galacturonic compounds, Dgalactose, L-rhamnose, acetylate, and trimethylamine (Prakash, Gopal, \& Kaviarasan, 2012). In Java and the Philippines, the bark, stems, and young leaves are used to treat rheumatoid arthritis, and the juice from leaves is used to help heal wounds (Vo, 1997). The resin contains necessary minerals for the body's metabolism, such as calcium, potassium, zinc, ferrite, magnesium, aluminum, manganese, and others. The mineral content in a beverage product derived from Sterculia foetida L. is summarized in Table 1.

Table 1. Mineral and heavy metal content of a beverage product

\begin{tabular}{llc}
\hline Content & & Value \\
\hline & $\mathrm{Ca}$ & 97.110 \\
& $\mathrm{~K}$ & 191.460 \\
& $\mathrm{Mg}$ & 97.310 \\
$\begin{array}{l}\text { Minerals } \\
\text { (mg.100g-1) }\end{array}$ & $\mathrm{Al}$ & 89.180 \\
& $\mathrm{Mn}$ & 0.950 \\
& $\mathrm{Fe}$ & 9.290 \\
& $\mathrm{Zn}$ & 0.540 \\
& $\mathrm{As}$ & 0.002 \\
Heavy metals & $\mathrm{Cd}$ & 0.002 \\
(mg.1-1) & $\mathrm{Hg}$ & 0.002 \\
\hline
\end{tabular}

Source: Nguyen, Le, and Truong (2016). 
Sterculia foetida L. seeds are edible and are used for making oil and cattle feed. Leaves contain $2.66 \%$ calcium and are also rich in protein and phosphorus (Niran \& Chanida, 2009). According to Sabria, Joao, Mariana, and Edna (2004), oil made from the seeds is rich in fatty acids that can be used for cooking, lighting, and processing cakes.

Table 2. Analytical data on Sterculia foetida L. seeds and oil

\begin{tabular}{lll}
\hline & Properly & Value \\
\hline Moisture & $9.20 \%$ \\
& Oil & $32.44 \%$ \\
& Acid value & 7.42 \\
Oil characteristics & Iodine value & 142.96 \\
& Saponification value & 154.78 \\
& Unsaponifiable matter & $1.11 \%$ \\
& Myristic acid & $1.65 \%$ \\
& Palmitic acid & $11.87 \%$ \\
& Heptadecanoic acid & \\
\hline Fatty acid & Margaric acid & $2.28 \%$ \\
\hline & Oleic acid & $12.86 \%$ \\
& Linoleic acid & $6.67 \%$ \\
\hline
\end{tabular}

Source: Kale, Vijaya, and Thakur (2011).

In light of current energy security and environmental polution concerns, biodiesel production from Sterculia foetida L. has a high potential as a solution for renewable energy. Oil from the seeds has a high acid value and a strong potential for creating biofuel (Bindhu et al., 2012; Silitonga et al., 2013). The GC-MS (Gas Chromatography-Mass Spectrometry) analysis for FAME (Fatty Acid Methyl Ester) of the seed oil showed that the oil consists of seven fatty acids (Table 2) (Kale et al., 2011).

When extracting leaves with ethanol, the extracted solution is antimicrobial, antifungal, antiprotozoal, and cytotoxic. These substances inhibit the growth of 
pathogens, such as Staphylococcus aureus and Escherichia coli. Thus, the ethanol extracts from the leaves may be used to produce antibiotic substances (Pierangeli, Rogelio, Josemaria, \& Windell, 2010; Prakash et al., 2012). The herbicidal potential of crude, column fractions and an isolated pure compound of seeds were assessed against four major Indian weeds: Calotropis gigantea, Parthenium hysterophorus, Datura metel, and Tridax procumbens. The weeds had limited seed germination, short, and root lengths (Pathipati \& Pala, 2010). The study of Pathipati, Pala, and Nagaiah (2010) indicated that the bioactive compound isolated from the leaves could act as a potent insecticide against Sitophilus oryzae, Callosobruchus chinensis, and Tribolium castaneum.

In addition, Sterculia foetida L. also has various applications in cosmetics for skin care. Strands of bark fiber and wood are used for furniture, packaging, paper pulp, chipboard, fiberboard, and industrial uses (Nguyen \& Vu, 2014).

\subsection{Resin tapping and storage}

Resins are among the most important non-wood products harvested from trees. They are also one of the oldest tree products used by humans. Most resins are harvested from trees by a process known as tapping. This involves the process of wounding the trunks of living trees to induce a resin flow, installation of a resin collecting system, and, in some cases, the possible application of a chemical stimulant to maintain resin flow. After 4-5 years of planting, trees 4-5 $\mathrm{m}$ tall and with an average diameter of $12 \mathrm{~cm}$ or more can be harvested for resin. The trees can be tapped throughout the year. Harvesting by tapping or drilling multiple holes at different locations, with each hole 2 $\mathrm{cm}$ in diameter and $2 \mathrm{~cm}$ in depth, are made on the trunk tree at distances from 20 to $25 \mathrm{~cm}$. The harvesting process is repeated for 2-3 days. Depending on the size and age of the trunk, the number of times resin can be harvested is at most 10-15 times per hole after wounding, self-healing and tapping to other holes (Nguyen \& Vu, 2014) (Figure 3). In addition, resin can be collected by cutting the top of branches. Medium-level or top branches are covered with plastic wrap and bound to obtain the best quality of resin and to prevent oxidization and impurities (Nguyen \& Vu, 2014).

Resin is available in a variety of sizes and colors: Opaque white, yellowishwhite, etc, depending on the location and age of the tree. When extracted from the tree, the resin must be classified immediately by quality. Then it is dried under sunny conditions from 1 to 2 days and stored in a nylon bag or clean plastic box to avoid moisture and outside air (Nguyen \& Vu, 2014).

\subsection{Propagation}

Sterculia foetida L. can be propagated through seeds, cuttings, grafting, and tissue culture. The original method of propagation was only by seeds. Seeds are collected on trees more than 10 years old and resin is not harvested for 1-2 years to ensure good quality (Nguyen \& Vu, 2014). There are several steps in the propagation process. Firstly, seeds are picked from healthy mother trees with good morphology. 
Secondly, seeds must undergo a variety of processes including drying to decrease humidity and storage at low temperature in a refrigerator to maintain seed quality. Then, after 2 to 3 weeks, the seeds should be sown. Seed scarification involves breaking, scratching, or softening the seed coat so that water can enter and begin the germination process. Hot water scarification involves putting the seeds into hot water $\left(40\right.$ to $\left.50^{\circ} \mathrm{C}\right)$ and allowing the seeds to soak in the water, as it cools, for 12 hours before being planted. In this case, the seeds are stored in straw, pots or polyethylene bags where the seed coat will be broken down over several days. The seeds then germinate and grow. Optimum germination can be expected after 1 to 3 weeks if the seeds were properly treated. Moreover, tree growth is dramatically fast at the beginning. The young seedlings reach a standard diameter of more than $3-4 \mathrm{~mm}$ at stump height and a height 35-45cm at about 3-4 months of age (Đặng \& Bùi, 2005; Nguyen, 2004; Nguyen, Nguyen, \& Dang, 2009; Pham, Phung, \& Tran, 2010). The percentage germination was observed to be $70 \%$ within 21 days with a 3:1 soil to manure ratio (Yashwant, 2014).

This plant is primarily planted for the purpose of collecting resin. Therefore, clonal propagation is considered the most important propagation method to ensure genotype traits for the next generation. Phung and Phung (2017) showed that treatment with NAA (Naphthyl Acetic Acid) at a concentration of 1,500ppm yielded the highest rooting percentage $(56.7 \%)$, and cuttings from one-year-old mother trees yielded the highest rooting percentage (83.3\%). On one hand, related to cutting season, the result illustrated that the highest rooting ratio of cuttings was in November - rainy season and the rooting percentage decreased rapidly during dry season. On the other hand, for the grafting method, the study showed that the highest survival percentage was in wedge grafting, which peaked at $84.5 \%$, and that a suitable time to apply this method is during the dry season. Anitha and Pullaiah $(2001,2002)$ described the possibility of propagation from tissue culture with various chemicals. Their studies discussed shoot regeneration from hypocotyl and shoot tip explants from seedlings. Different cytokinin fortified in the media and BAP (6-Benzylaminopurine) $(2 \mathrm{mg} / \mathrm{l})$ induced 4-5 shoots from shoot tip explants followed by 3-4 shoots from hypocotyl explants. Kinetin and TDZ (Thidiazuron) at different concentrations induced 1-2 shoots from shoot tip explants, while hypocotyl explants developed only a white friable callus towards the cut ends. IAA (Indole-3-acetic acid) at $2 \mathrm{mg} / \mathrm{l}$ has found to be best for highest frequency of root formation from the cut ends of the micro shoots without callus formation. The regenerated plantlets acclimatized under field conditions with a $40 \%$ survival rate. Thus, Sterculia foetida L. can be propagated in many different ways.

\subsection{Planting}

Sterculia foetida L. shows good adaptability to soil, but probably requires soils with sufficient moisture for optimum development (Orwa et al., 2009). The soil layer should be thicker than $40 \mathrm{~cm}$ and the stone proportion should be less than $40 \%$. This species should not be planted in lowland drainage and flooded lands (Nguyen, 2004; Nguyen \& Vu, 2014). According to Pham et al. (2010), Sterculia foetida L. grew very well when using organic fertilizer combined with coal in various types of sand. Depending on the quality of the soils, the planting density can vary from 400 to 1,100 
trees/ha (Nguyen \& Vu 2014) or, with a density 550 trees/ha, if mixed with agricultural crops, such as pineapples, bananas, or cashews. The amount of fertilizer for each tree should be between $3-5 \mathrm{~kg}$, and should be applied early in the rainy season. Additionally, young trees need good care after planting for 2 to 3 months and protection from weeds while developing their defensive root systems to a depth of $1 \mathrm{~m}$. During the second and third years, general care twice a year is required (Đặng \& Bùi, 2005; Nguyen et al., 2009). Yashwant (2014) reported a mean height of $99.96 \pm 0.59 \mathrm{~cm}$ after six months from the date of germination and, after one year, the mean height and girth size were $145.44 \pm 0.39 \mathrm{~cm}$ and $7.2 \pm 0.23 \mathrm{~cm}$, respectively.

\subsection{The potential for developing this plant in the dry areas of Vietnam}

Drought is a common disaster in Vietnam, ranking third after storms and floods. Droughts adversely affect social life, economic development and the environment. According to climate change scenarios, droughts are expected to increase in Vietnam in the coming decades (MONRE, 2016). At the end of 2014, El Nino dramatically affected Vietnam, with high temperatures and the lack of rainfall causing drought and salinity intrusions. Severely affected areas included southern portions of Central Vietnam, the Central Highlands and the Mekong Delta (CSCNDPV, 2016). Therefore, the selection of suitable trees that adapt well to drought and require less water is especially important to increase local economic, social and environmental development of these areas. In recent years, the selection of suitable species for dry lands has brought positive trends in the agriculture sector (Hoang \& Vo, 2013; Nguyen, Pham, \& Cao, 2015; Pham et al., 2010; \& Tran, 2013).

Sterculia foetida L. can be planted in areas with low rainfall (600-700 $\mathrm{mm}$ per year) and with soil and air temperatures up to $40-45^{\circ} \mathrm{C}$ during 6 or 7 dry months. The trees can grow on poor, bare hills on bedrock of yellow-red faralite, gray soil on granite, ancient silt, or sandstone. Well-rooted specimens can even withstand $80-90 \%$ sand or mixtures with stones or rocks (Nguyen et al., 2009). Therefore, the trees can grow well in nutrient-poor conditions and dry soils. They are deciduous in late winter; Young leaves and flowers grow at the beginning of the rainy season from March to April each year (Đặng \& Bùi, 2005; Nguyen \& Vu, 2014). Sterculia foetida L. is distributed naturally in the Central Highland provinces of Kontum, Gialai, Daklak, and Lamdong and the southern central coastal provinces of Khanhhoa, Ninhthuan, and Binhthuan (Figure 2).

In Ninhthuan, it is found in many places, especially many coastal areas in Phuocdinh commune, Phuocdinh district. Also, the trees are planted in parks and streets of many major cities, including Hanoi, Hochiminh City, and Buonmethuot (Nguyen \& $\mathrm{Vu}, 2014)$. MARD (2014) has issued a list of major species for plantation forests based on forest ecological zones and has selected Sterculia foetida L. as one of the main trees for afforestation and production forests. Thus, it will be planted and restructured as an agriculture crop to reduce climate change in the period from 2020 to 2030 in Ninhthuan province (Ninhthuan People's Assembly, 2016). Research by Pham et al. (2010) also indicated that it is one of seven species that should be planted in Ninhthuan and 
Binhthuan provinces because it is a suitable crop for a wide variety of soil types and has a wide range of applications that have a huge impact on the environment and economic development of these areas. From the results of the project "Building afforestation model of Sterculia foetida in the dry border area of Daklak province", we acknowledge that Sterculia foetida has grown well in the dry land of this province (Figure 3)

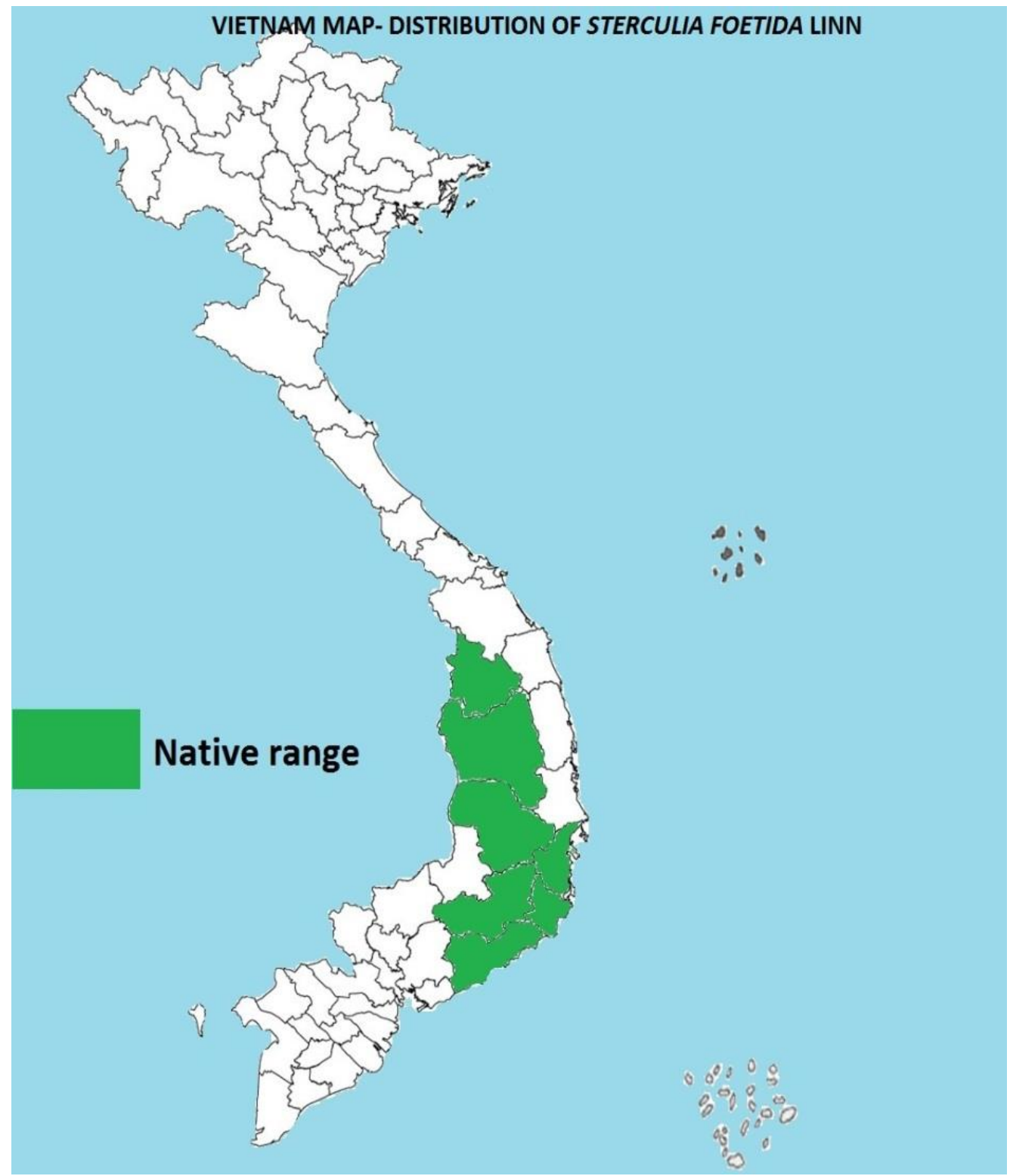

Figure 2. Map showing the distribution of native areas of Sterculia foetida $\mathbf{L}$. in Vietnam

Source: Nguyen and Vu (2014) (edited by the authors). 


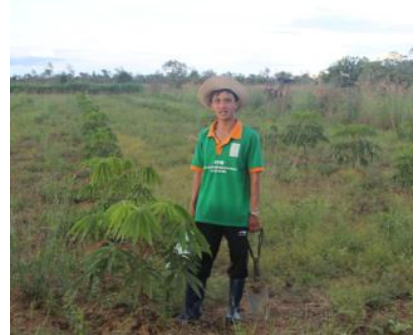

(a)

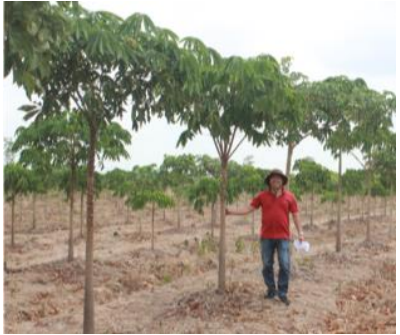

(b)

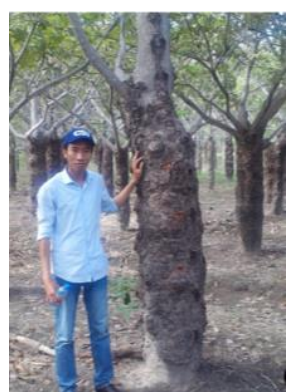

(c)

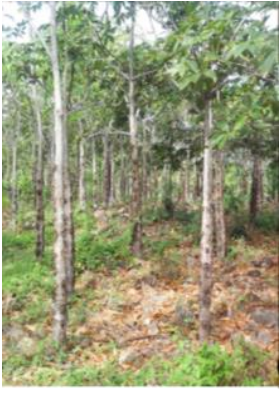

(d)

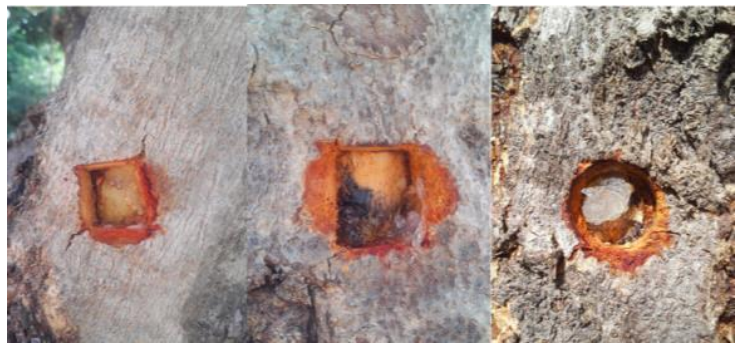

(e)

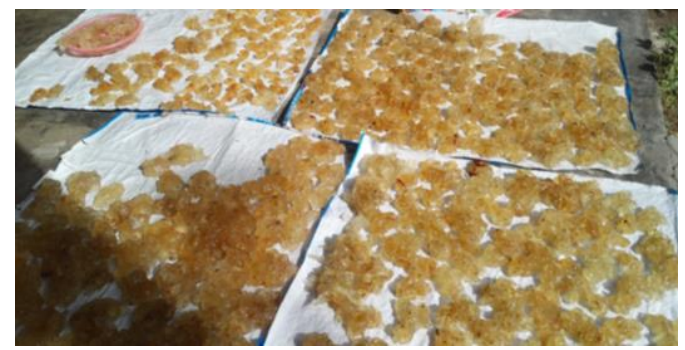

(f)

Figure 3. Planting and resin tapping of Sterculia foetida $\mathrm{L}$.

Note: a) 4 months; b) 20 months at Daklak province; c) Over 20 years of resin tapping at Ninhthuan province; d) Grown in high stone content soil; and e \& f) Resin harvesting.

\section{CONCLUSIONS}

Sterculia foetida $\mathrm{L}$. is multi-purpose tree that is often harvested from the wild, providing a popular food, as well as medicines and a range of materials for local use. However, in order to develop this species, it is necessary to develop a breeding strategy, select the best elite trees that have fast growth, much resin, good quality, and are suitable for a variety of soil types. At the same time, there should be built a value chain linking products and trade marks to ensure the development of this species is sustainable and well adapted to climate change.

\section{REFERENCES}

Anitha, S., \& Pullaiah, T. (2001). In vitro propagation of Sterculia foetida Linn. (Sterculiaceae). Plant Cell Biotechnology and Molecular Biology, 2(3-4), 139144.

Anitha, S., \& Pullaiah, T. (2002). Shoot regeneration from hypocotyl and shoot tip explants of Sterculia foetida L. derived from seedlings. Taiwania, 47(1), 62-69.

Bindhu, C., Reddy, J. R. C., Rao, B. V. S. K., Ravinder, T., Chakrabarti, P. P., Karuna, M. S. L., \& Prasad, R. B. N. (2012). Preparation and evaluation of biodiesel from Sterculia foetida Seed oil. Journal of the American Oil Chemists' Society, 89(5), 891-896. 
CSCNDPV. (2016). Report droughts, salinity intrusion and response solutions. Hanoi, Vietnam: Vietnam Steering Committee for Natural Disaster Prevention and Control (in Vietnamese).

Đặng, Đ. B., \& Bùi, A. T. (2004). Cây Trôm, một cây quý đang được phát triển ở Ninh Thuận. Ninh Thuận, Việt Nam: Sở Nông nghiệp và Phát triển Nông thôn tỉnh Ninh Thuận.

Hoang, P. M., \& Vo, D. H. (2013). Assessment of mixed protection forest plantation model between Dipterocarpus alatus, Hopea odorata, Ailanthus malabarica established in Songcau district, Phuyen. Journal of Forest Science, 1, 401-409 (in Vietnamese).

Hocking, G. M. (1997). A dictionary of natural products (2 ${ }^{\text {nd }}$ ed.). New Jersey, USA: Plexus Publishing.

Kale, S. S., Vijaya, D., \& Thakur, H. A. (2011). Analysis of fixed oil from Sterculia foetida Linn. International Journal of Pharmaceutical Science and Research, 2(11), 2908-2914.

Kavitha, M., Vadivu, R., Radha, R. (2015). A $\quad$ review on Sterculia foetida Linn. Research Journal of Pharmacognosy and Phytochemistry, 7(4), 239-244.

Lim, T. K. (2011). Edible medicinal and non-medicinal plants. Berlin, Germany: Springer Publishing.

MARD. (2014). List of major tree species for production forest plantation and list of key plant species for afforestation by forest ecological zones. Hanoi, Vietnam: The Ministry of Agriculture and Rural Development (in Vietnamese).

MONRE. (2016). Scenario of climate change and sea level rise for Vietnam. Hanoi, Vietnam: The Ministry of Natural Resources and Environment (in Vietnamese).

Nguyen, T. T. T., \& Vu, N. H. (2014). Planting: Sterculia foetida. Hanoi, Vietnam: The Ministry of Agriculture and Rural Development (in Vietnamese).

Nguyen, T. L. A., Le, N. H. M., \& Truong, V. T. (2016). Manufacture of soft drink from Sterculia foetida latex. Journal of Science and Technology - The University of Danang, 3(100), 103-107 (in Vietnamese).

Nguyen, X. P. (2004). Research on household cultivation of Sterculia foetida in Ninhphuoc district, Ninhthuan province. (Graduation Thesis), Nonglam University, Vietnam (in Vietnamese).

Nguyen, X. Q., Nguyen, V. C., \& Dang, V. T. (2009). Techniques for planting some multi-purpose tree species. Hanoi, Vietnam: Agricultural Publishing.

Nguyen, X. Q., Pham, D. S., \& Cao, V. L (2015). Growth and productivity of timber plantations of some main species in Binhdinh and Phuyen, South Central region. Journal of Forest Science, 4, 456-462 (in Vietnamese). 
Ninhthuan People's Assembly (2016). Resolution on restructuring the agricultural sector in response to climate change response to 2020 and vision to 2030. Ninhthuan, Vietnam: Ninhthuan People's Assembly (in Vietnamese).

Niran, V., \& Chanida, P. (2009). Fatty acids of Sterculia foetida seed oil. Journal of Health Research, 23(3), 123-130.

Nirbhay, S. S., \& Mehta, S. C. (2015). Mazaing tree Sterculia foetida found in Dhar and Ujjain (M.P.) India. An International Refereed Research Journal, 1, 28-31.

Orwa, C., Mutua, A., Kindt, R., Jamnadass, R., \& Anthony, S. (2009). Sterculia foetida. Retrieved from http://worldagroforestry.org/output/agroforestree-database.

Pathipati, U. R. \& Pala, R. (2010). Insecticidal activity of (2n-octylcycloprop-1-enyl)octanoic acid (I) against three coleopteran stored product insects from Sterculia foetida L.. Journal of Pest Science, 83, 273-279.

Pathipati, U. R., Pala, R., \& Nagaiah, K. (2011). Allelopathic effects of Sterculia foetida L. against four major weeds. Alleloppathy Journal, 28(2), 179-188.

Pham, H. H. (2000). An illustrated flora of Vietnam, episodes I. Hochiminh City: Young Publishing (in Vietnamese).

Pham, T. D., Phung, V. K., \& Tran, D. T. (2010). Nghiên cúu kỹ thuật trồng một số loài cây bản địa có giá trị kinh tế vùng khô hạn tỉnh Ninh Thuận, Bình Thuận. Được truy lục từ http://vafs.gov.vn/vn/wp-content/uploads/sites/2/2012/02/20cay\%20 chiu\%20ha.pdf.

Phung, V. K., \& Phung, V. K. (2017). Study propagation of Sterculia foetida L. by cutting and grafting method. Vietnam Journal of Forest Science, (Special issue), 2-7.

Pierangeli, G. V., Rogelio, N. V. J., Josemaria, M. D., \& Windell, L. R. (2010). Antimicrobial activity, cytotoxicity, and phytochemical screening of Ficus septica Burm and Sterculia foetida L. leaf extracts. Journal of Medicinal Plants Research, 4(1), 58-63.

Prakash, Y. G., Gopal, V., \& Kaviarasan. L. (2012). Promising pharmaceutical prospective of "Java olive" Sterculia foetida L.. International Journal, 2, 93-96.

Sabria, A. P., Joao, H. G. L., Mariana, H. C., \& Edna, E. K. (2004). Evaluation of a methylation procedure to determine cyclopropenoids fatty acids from Sterculia striata St. Hil. Et Nauds seed oil. Journal of Chromatography, A, 235-239.

Silitonga, A. S., Ong, H. C., Masjuki, H. H., Mahlia, T. M. I., Chong, W. T., \& Yusaf, T. F. (2013). Production of biodiesel from Sterculia foetida and its process optimization. Fuel, 111, 478-484

Tran, D. R. (2013). Đánh giá sinh truơng và hiệu quả kinh tế của Keo lai ở Quảng Trị. Được truy lục từ http://vafs.gov.vn/vn/wp-content/uploads/sites/2/2011/09/8Ruong.-Sinh-truongKeolaitaiQuangTri.pdf.

Vo, V. C. (1997). Dictionary of medicinal plants in Vietnam. Hanoi, Vietnam: Medical Publishing (in Vietnamese). 
Yashwant, R. (2014). Growth and development of rare tree species Sterculia foetida Linn. in district Meerut, (U.P.) India. International Journal of Science and Research, 3(6), 324-327. 